\title{
The Spirit of generosity: A new economic dispensation in the wake of Pentecost?
}

\author{
Wessels, Johannes \\ North-West University \\ johannes.wessels@nwu.ac.za
}

\begin{abstract}
The nature of the economic formation in the Early Church has been widely debated through the centuries. In his work, Das Kapital, Karl Marx quotes Acts 2:44-45, and even supplies these verses as his reason for hating God. As in the case of Marx and his compatriots, several current biblical scholars (especially those from poor communities) are still disillusioned by their view that the initial drive towards sharing money and property have soon been watered down by the Early Church.

This article's main focus is on the way in which reciprocity sheds new light on the economics of the Early Church. It concludes that economics in the Apostolic Era and the Early Church introduced a clear departure from the monetary policies exercised in the First Century Temple in Jerusalem, and in the Synagogues. Not only the main 'economic' events in Acts, but also the subsequent results in developing congregations, then and now, are discussed.
\end{abstract}

Key words

Holy Spirit; generosity; poverty; Acts; economy

\section{Introduction}

In our modern society, where academics are discussing the relevance of what some may call (positively or negatively) an old time religion, we cannot escape from the fact that the world, and especially Third World countries like Africa is in devastation. Even though there is progress in the battle against poverty in Sub-Saharan Africa (Fosu 2015:1), there are still many people in many parts of South Africa and its Northern neighbours that live underneath the poverty line. 
A lot of this may be ascribed to politics rather than religion. We also know that you can't discuss many of these issues without interpreting it within the economic framework of poverty. But whatever name tag we may give to the problems around us, it all boils down to the one important question...

How are we actively involved in preventing the dawning catastrophe of a predicted worldwide food shortage? What will the contribution of these few days be to the current situation that we may find ourselves in? I deem it to be essential to revisit the First Century Mediterranean, and to rediscover the influence and the power of the Holy Spirit in the early church.

The nature of the economic formation in the Early Church has been widely debated through the centuries. In his work, Das Kapital, Karl Marx quotes Acts 2:44-45, and even supplies these verses as his reason for hating God (As in the case of Marx and his compatriots, several current biblical scholars (especially those from poor communities) are still disillusioned by their view that the initial drive towards sharing money and property have soon been watered down by the Early Church.

In the $21^{\text {st }}$ century we are surely not always aware of the harsh realities of the first century environment. We often soften up the experiences, guidance and instructions of the apostles as mere 'mimicry', 'rhetoric', and 'dramatization'. This article aims to contribute to a new appreciation of the Holy Spirit, its influence in the Early Church, and its practical relevance for today.

\section{A disillusioned church}

The practice of care for the poor by the Early Church is often viewed as being a mere continuation of the strong emphasis on the care for the poor in the Old Testament. The economic crisis during Jesus' earthly life, however, was much more than exploitation from the side of the Roman Empire. The harsh economic exploitation of the inhabitants of Palestine, exerted, amongst others, by the Pharisees in the First Century CE, certainly contributed to the difficult economic circumstances of the Jews.

An important theory is proposed by Nissen (1984:16), who argues that the Pharisees largely contributed to poverty in Israel. In his treatment of 
'the poor in the context of Jesus' ministry', he argues that the Pharisees ${ }^{1}$ used their exegetical authority ${ }^{2}$ on the law to marginalize the peasants to their own advantage. In what was previously described as 'economical alienation', John $(7: 47-49)^{3}$ provides the evidence that the peasants, who were the outcasts of the established culture of their days, clashed with the Pharisees.

According to Nissen (1984:11-12) 'Jewish society rested on a religious ideology, according to which all those who were not true Israelites... were despised, rejected and marginalised. ${ }^{4}$ Nissen's theory does not only put the instruction of Jesus to the Pharisees in Luke 11:42, to 'give what is inside the dish to the poor' into perspective, but provides a different perspective on Jesus' vehement judgement on the oppression and lack of justice in his time. In a sense the 'Sermon on the plain' (Lk 6:20-26), ${ }^{5}$ which has been the object of much scholarly debate (Ling 2006:123-131), makes much more sense, when partially directed at the 'economical alienation' of the Pharisees:

1 Traditionally the Pharisees were viewed (cf. Blomberg 1999:101) as being closer to the Peasants, whilst the Sadducees were the 'rich', seeking the favour of the government. Though I do not deny the existence of a rich faction of Sadducees, the Pharisees' power struggle during the Intertestamental period in Palestine is testimony to the position of power that at least some factions within the Pharisees aspired to attain.

2 The presence of power structures in the oppression of the peasants is also articulated by Volschenk (2003:422).

3 Jn 9:47-49: ${ }^{47}$ You mean he has deceived you also?' the Pharisees retorted. ${ }^{48}$ Has any of the rulers or of the Pharisees believed in him? ${ }^{49}$ No! But this mob that knows nothing of the law - there is a curse on them.'

4 I do believe that Nissen (1984:12) takes this too far when arguing that 'the political reality that really controlled the religious, social and economic life of the people was an oppressive Jewish theocracy rather than the Roman Empire', but he does shed some valuable light on Jesus' behaviour towards the Pharisees. There are scholars who view the role of the Pharisees in the First Century in a positive light (Culbertson 1982:539561; Sanders (1992), but I still hold the traditional view (cf. Nissen 1984:18-19) of the Pharisees as being a sect which proved burdensome in many aspects to the masses.

5 Mt 6:20-26: ${ }^{20}$ Looking at his disciples, he said: 'Blessed are you who are poor, for yours is the kingdom of God. ${ }^{21}$ Blessed are you who hunger now, for you will be satisfied. Blessed are you who weep now, for you will laugh. ${ }^{22}$ Blessed are you when men hate you, when they exclude you and insult you and reject your name as evil, because of the Son of Man. ${ }^{23}$ Rejoice in that day and leap for joy, because great is your reward in heaven. For that is how their fathers treated the prophets. ${ }^{24}$ But woe to you who are rich, for you have already received your comfort. ${ }^{25}$ Woe to you who are well fed now, for you will go hungry. Woe to you who laugh now, for you will mourn and weep. ${ }^{26}$ Woe to you when all men speak well of you, for that is how their fathers treated the false prophets." 
The 'Beatitudes' and the 'woes' in the 'Sermon on the plain' (Lk 6:20-26), was directed at the larger circle of disciples, with the great multitude of people overhearing (Kim 1998:26; Nolland 1989:281). ${ }^{6}$ Read from a perspective of the 'poor peasants', they could surely associate with being poor, hungry, sad and hated, by the Pharisees. The feeling of being marginalised, i.e. 'excluded', would not have been foreign to them (Neyrey 2002:1). The qualification 'because of the Son of Man' (v. 22) surely adds a new dimension (and in a sense a prerequisite) to the blessings, but the reality of oppression would not have been foreign to them.

On the other hand, the Pharisees would probably recognise being called 'rich', 'well fed' and honoured in the public opinion. To my view the continuation between the post-exilic times and the behaviour of the Pharisees are strengthened by the reference to 'fathers' and 'false prophets'. Jesus is here in a sense 'radicalising the tradition' (Birch 1975:599), and questioning the 'norm' (Hollenbach 1987:61), by proclaiming a reversal of circumstances for both these groups.

Further evidence for Jesus' association with the peasants or poor of his day (contra the Pharisees), is the passage on the great judgement in Matthew 25:31-46. There Jesus not only identifies with the poor, but actually equates acceptance of him with ministering to the needs of the poor (Birch 1975:599), as verse 45 clearly shows. ${ }^{7}$ Other clear indications of the economical nature of Jesus' criticism of the Pharisees, are his command to exercise additionally 'justice, mercy and faithfulness' (Mt 23:23; Lk 11:24) on top of their tithing, and his cleansing of the tables in the temple (Mt 21:12-17, Mk 11:15-19; Lk 19:45-48; Jn 2:13-22).

6 There is also a view by Schottroff \& Stegemann (1986:71) that the first part was addressed to the disciples only, and the 'woes' to the larger crowd, but this is successfully repudiated by Kim (1998:26).

7 Mt 25:45: 'He will reply, 'I tell you the truth, whatever you did not do for one of the least of these, you did not do for me." 
Jesus also directs an unmistakable accusation at the teachers of the law, who devoured the houses of the widows (Lk 20:46-47), ${ }^{8}$ echoing the accusation of Micah (2:1-2). ${ }^{9}$

It is widely assumed that Jesus and his disciples did hand out alms on a regular basis. Judas' remark in John 12:5, suggesting that Mary should have rather sold the bottle of perfume and give it to the poor, can be interpreted as pointing to a custom exercised by Jesus and his disciples (Pettit 1998). The reference to Jesus 'doing good deeds and healing people' in Acts 10:38 probably points to the same custom.

In retrospect, it is evident that widespread poverty was a reality in the time of Jesus, and that he addressed it in numerous instances. He reprimanded the oppressors and the greedy, but also associated with the poor of his day, being one of the poorest himself. The worst, however, was yet to come. In the following years the economic situation in Jerusalem deteriorated drastically.

\subsection{Poverty and the early church in Jerusalem and Caesarea}

In the twenty years after Jesus' death, especially approaching the year 50 $\mathrm{AD}$, the situation in Palestine became almost unbearable for the 'begging poor' ${ }^{10}$ Not only was there no relief from the harsh Roman government, but several famines (Gapp 1935:260-261) in the Mediterranean contributed to a dire need for assistance in the early church.

8 Lk 20:46-47: ${ }^{46}$ Beware of the teachers of the law. They like to walk around in flowing robes and love to be greeted in the market-places and have the most important seats in the synagogues and the places of honour at banquets. ${ }^{47}$ They devour widows' houses and for a show make lengthy prayers. Such men will be punished most severely.'

9 In the light of the above it must be asked whether Jesus chose the 'option for the poor', and alienated the rich and wealthy of his time. Nissen (1984:16-18) is right in pointing out that he visited and assisted the rich, amongst whom one may count Jairus (Mt 9:1826), Nicodemus (Jn 3:1-21), Joseph of Arimathea (Mt 27:57-61), and Zacchaeus (Lk 19:1-10), although he did not refrain from proclaiming the implications of the gospel, especially the need for 'giving to the poor', whenever in was required

10 The dire situation in Jerusalem around $50 \mathrm{AD}$ is well documented in the works of inter alia Gapp (1935). 
Immediately after Pentecost, and the inception of the early church, the practise of love 'communism',"1 or rather 'communalism' (Blomberg 1999:163) is recorded in Acts 2:44-45, ${ }^{12}$ and in Acts 4:32. ${ }^{13}$ This sharing of goods is often contributed to the hypothesis that the apostles and new believers placed the emphasis on the 'spiritual' rather than the material, in expecting Christ's return (Bird 1982:155; Nissen 1984:88). Harrison (1986:98-99) assumes that this sharing of goods eventually 'drained' the resources of the believers, which resulted in poverty amongst Christians in Jerusalem, and the subsequent plea from their leaders to Paul to 'remember the poor' (Gal 2:10).

Despite the claims above there is enough reason to believe that the selling of goods by believers addressed everyone's needs (Acts 2:45), and it is stated specifically that the sale of land and houses took place from 'time to time' (Acts 4:34) ${ }^{14}$ It is therefore improbable that there was a total 'shedding' of all goods by the wealthier members (Blomberg 1999:162).

In the rest of Acts the attitude of the believers is apparent, especially in the healing of the crippled beggar at the temple gate (Acts 3:1-10). Peter and John's answer in verse 6 might raise eyebrows, as it could be argued that there had to be money after everything was sold. It must be remembered, however, that there was no real excess, as the first believers were very poor despite the contributions of their wealthier members, and therefore not much was left for charity (Bird 1975:157).

After relating the joyful occasion of Barnabas' gift, Luke also provides us with the painful event of Ananias and Sapphira's treachery (Acts 5:1-11). Even though this may seem an improper punishment, it must be noted

11 The term 'love Communism' is often used to describe the way in which the first Christians sold their possessions and shared everything with one another (Birch 1975:601; Nissen 1984:86). Blomberg (1999:163) points to the fact that there are actually very little correspondence between First Century 'communalism' and Communism as presented by Marx. Marx forced communism by legislation, and in Communism not only the consumption, but the production was shared as well.

12 Acts 2:44-45: ${ }^{44}$ All the believers were together and had everything in common. ${ }^{45}$ Selling their possessions and goods, they gave to anyone as he had need.'

13 Acts 4:32: ${ }^{32}$ All the believers were one in heart and mind. No-one claimed that any of his possessions was his own, but they shared everything they had.

14 The participium here, $\pi \omega \lambda \mathrm{ov} \nu \tau \varepsilon \varsigma$ indicates an event over time, and not a once-off or purely historical event. 
that there is a certain correspondence with the crime of Achan here, the inception of a new era for God's people, as well as the sin of covetousness (Haenchen 1971:237).

Not long after this tragic incident, tensions between the Greeks and the Jews developed due to discrimination towards the Greek widows (Acts 6:17). In the Old Testament the widows were regarded as the responsibility of the people, and even received part of the tithe. This issue, which had the potential to create a schism in the church, was solved by appointing seven deacons, and (as in the case with Ananias and Sapphira) eventually contributed to the growth of the church, and the number of priests that adhered to Christian faith is mentioned specifically (Acts 6:7). ${ }^{15}$

The attempt of Simon the Sorcerer to buy the gift of the Spirit (Acts 8:9-25), and Dorcas' (9:36) as well as Cornelius' (Acts 10:2,4,31) daily almsgiving are examples of the way that the economic aspect was an inseparable part of the early church. There are also regular references to rich persons, for example the owner of the house where 120 people were able to gather in the upper room during Pentecost (Acts 2:1) and Cornelius (Acts 10:1). The rest of Acts contains several references to poverty and related aspects. This will be discussed in the next chapter, as these portions are strongly connected to Paul's ministry.

In the Lucan account of Paul's farewell before his final departure for Jerusalem (Acts 20:33-35), ${ }^{16}$ Paul explicitly states that he has worked hard to provide for his fellow workers as well as for the poor. He also reiterates the words of Jesus, 'to give is better than to receive'.

\subsection{Poverty amongst Jewish believers in the Diaspora}

That the letter of James takes a strong stand against oppression and neglect of the poor, is widely accepted, and therefore it will be dealt with briefly.

15 Acts 6:7: 'So the word of God spread. The number of disciples in Jerusalem increased rapidly, and a large number of priests became obedient to the faith.'

16 Acts 20: 33-35: ${ }^{33}$ I have not coveted anyone's silver or gold or clothing. ${ }^{34}$ You yourselves know that these hands of mine have supplied my own needs and the needs of my companions. ${ }^{35}$ In everything I did, I showed you that by this kind of hard work we must help the weak, remembering the words the Lord Jesus himself said: 'It is more blessed to give than to receive.' 
Written to 'the twelve tribes in the Diaspora' (Jas. 1:1), ${ }^{17}$ this message provides good contextual evidence regarding poverty in the remote congregations of the Early Church. In line with Matthew 9:13 and 23:23, religion without mercy is regarded as worthless in James 1:26-27. ${ }^{18}$ These verses underline 'the importance of caring for orphans and widows, two of the four cardinal categories of poor in the Hebrew Scriptures' (Davids 2005:355).

In pointing out the religious background of the next passage of note, being James 2:1-13, Ling (2006:133) draws certain parallels to the parable of the rich man and Lazarus (Lk 16:19-31) and Jesus' accusation (Lk 20:46-47) of the 'teachers of the Law' as 'devouring the widows'. ${ }^{19}$

Even though keeping in mind that, as in the previous passage this is only an example, this is a clear reference to the 'begging poor', not having clothes or daily food ${ }^{20}$ in James 2 verses 15 and $16 .{ }^{21}$ The believer is called upon to assist the beggar in hard material terms, rather than just providing him with a spiritual blessing.

17 The nature of James' addressees is disputed, but the proposal of Martin (1988:11), calling them '... compatriots of the messianic faith whom he regards also as one in kinship with ethnic Israel in the international arena' will suffice here.

18 Js 1:26-27: ' ${ }^{26}$ If anyone considers himself religious and yet does not keep a tight rein on his tongue, he deceives himself and his religion is worthless. ${ }^{27}$ Religion that God our Father accepts as pure and faultless is this: to look after orphans and widows in their distress and to keep oneself from being polluted by the world.'

19 Ling (2006:133) points to the religious setting of both James 2 (the temple) and Luke 20 (the synagogue), as well as the reference to clothes, which is present in all three passages, as well as the position of honour that the teachers of the Law, or the rich man takes. This kind of discrimination was not acceptable amongst the believers (Davids 2005:355). In discussing this passage Ling (2006:133) concludes that 'we find the contrasted with the 'rich' in terms of their religious social practice', and that there is 'no simple social or economic opposition' present in this text. Even if we should ignore the 'shabby clothes' of the 'poor man', the last part of this passage shows some clear economic markers, especially if viewed in terms of economic marginalisation by Jewish religious leaders.

20 As shown in 5.2.2.1, the begging poor lacked 'daily bread', and were struggling for survival. It is against this background that the Lord's prayer (Mt 6:11; Lk 11:3), when Jesus asks for his daily bread, is understood better, since He and his disciples often did not have food at hand.

21 Js 2:15-16: ${ }^{15}$ Suppose a brother or sister is without clothes and daily food. ${ }^{16}$ If one of you says to him, 'Go, I wish you well; keep warm and well fed, but does nothing about his physical needs, what good is it?' 
In conclusion, one has to comment on James 5:1-11, as directly touching on the aspect of the 'economic alienation'. Verses 5-11 does not only resemble a funeral rite of the rich (Batten 2007:22), but verse 1-6, and 7-11 forms in a sense a 'reversed sermon on the plain', where the judgment is delivered before the blessing is bestowed upon the oppressed. The agricultural setting of this passage is noteworthy, as well as the frequently recurrent themes of 'clothes, hoarding, the last days, oppression and exploitation, murder, and abuse of power.' Eventually it is not the call of the wealthy Pharisee that

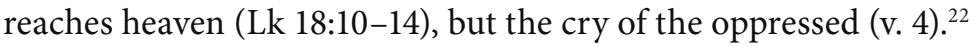

Despite the difference in scholarly opinion regarding the exact addressees of this book, it is evident that 'the poor' in the context of James still suffered oppression and exploitation, whether from Jewish religious leaders and elite, or from Roman officials. This is inter alia supported by the analysis of Davids (2005:355), who argues that if ' 47 verses out of 105 in the Letter, or close to $45 \%$, have an economic theme', this was clearly 'important to James' (Davids 2005:355).

\subsection{Poverty in the Pauline letters}

In the Pauline corpus, Paul often links his labour and 'working free of charge' to his concern for the poor. In Galatians 2:1023 Paul refers to his undertaking to remember the poor, and reiterates that it was something that he was eager to do.

In 1 Corinthians $16: 1-2^{24}$ he encourages the congregation to save up weekly for the poor in Jerusalem. In 2 Corinthians 8 and 9 he elaborates on the motivation for collection for the poor in Jerusalem. The arguments

22 Js 5:4: 'Look! The wages you failed to pay the workmen who mowed your fields are crying out against you. The cries of the harvesters have reached the ears of the Lord Almighty.'

23 Gal 2:10: 'All they asked was that we should continue to remember the poor, the very thing I was eager to do.'

241 Cor 16:1-2: ' ${ }^{1}$ Now about the collection for God's people: Do what I told the Galatian churches to do. ${ }^{2}$ On the first day of every week, each one of you should set aside a sum of money in keeping with his income, saving it up, so that when I come no collections will have to be made.' 
in 2 Corinthians $11: 7-9^{25}$ and $12: 13-16^{26}$ are important in portraying a development from Paul's initial explanation in 1 Corinthians 9 for offering the gospel free of charge. It is significant that he does not want to be 'a burden' to the congregants, and them not having to 'save up' for him as their spiritual father. Paul's portrayal of himself as an example, ${ }^{27}$ i.e. to work hard with his hands in order to evade poverty, is evident in his admonitions to the Thessalonians. ${ }^{28}$

Paul himself definitely knew what it was to be 'in need', 'be hungry', and experience 'want', and that his experiences of having plenty and being 'well fed' probably related more to his upbringing and Pharisaic background than to his life as a missionary (Php 4:12). ${ }^{29}$

Paul approached the financial outlays of the churches in his time from a holistic point of view, and was very conscious of which church would be

252 Cor 11:7-9: ${ }^{7}$ Was it a sin for me to lower myself in order to elevate you by preaching the gospel of God to you free of charge? ${ }^{8} \mathrm{I}$ robbed other churches by receiving support from them so as to serve you. ${ }^{9}$ And when I was with you and needed something, I was not a burden to anyone, for the brothers who came from Macedonia supplied what I needed. I have kept myself from being a burden to you in any way, and will continue to do so.'

262 Cor 12:13-16: ${ }^{{ }^{13}} \mathrm{How}$ were you inferior to the other churches, except that I was never a burden to you? Forgive me this wrong! ${ }^{14}$ Now I am ready to visit you for the third time, and I will not be a burden to you, because what I want is not your possessions but you. After all, children should not have to save up for their parents, but parents for their children. 15So I will very gladly spend for you everything I have and expend myself as well. If I love you more, will you love me less? ${ }^{16} \mathrm{Be}$ that as it may, I have not been a burden to you.'

27 Paul's use of his manual labour is also seen in the other undisputed letters of Paul (1 Cor 4:16, Php 3:12-17), the disputed letters of Paul (2 Thess 3:7-10), as well as the Lucan account of Paul's speech (Acts 20:35).

281 Thess 2:6-9: ' ${ }^{6}$ We were not looking for praise from men, not from you or anyone else. As apostles of Christ we could have been a burden to you, ${ }^{7}$ but we were gentle among you, like a mother caring for her little children. ${ }^{8}$ We loved you so much that we were delighted to share with you not only the gospel of God but our lives as well, because you had become so dear to us. ${ }^{9}$ Surely you remember, brothers, our toil and hardship; we worked night and day in order not to be a burden to anyone while we preached the gospel of God to you.'

1 Thess 4:11-12: ${ }^{11}$ Make it your ambition to lead a quiet life, to mind your own business and to work with your hands, just as we told you, ${ }^{12}$ so that your daily life may win the respect of outsiders and so that you will not be dependent on anybody.'

29 Php 4:11-12: ${ }^{11} \mathrm{I}$ am not saying this because I am in need, for I have learned to be content whatever the circumstances. ${ }^{12} \mathrm{I}$ know what it is to be in need, and I know what it is to have plenty. I have learned the secret of being content in any and every situation, whether well fed or hungry, whether living in plenty or in want.' 
better disposed to contribute to a specific cause, while not totally negating others.

Paul chose to focus congregations such as the Corinthians to largely contribute towards the collection, forfeiting his own allotment in terms of salary, assuring that the poor had access to the 'Good News', and that Paul would at least share in the priceless profit of the gospel (Wessels 2010:166). In the same chapter Paul also shows himself to become weak on behalf of the weak, a designation which certainly bears an economic component here (Longenecker 2010:309).

It has also been shown that Paul's trade as tentmaker (or leather worker) did not only serve as a means of sustenance for Paul, but also provided a tangible example of the importance of working hard, not being idle. As mentioned earlier, Paul is quoted by Luke in Acts 20:35 that the income derived from this labour was also used to support his fellow workers and the poor.

Even though Paul may be viewed as a headstrong individual, I have argued that Paul surely focused in many ways on 'the other' in his life, especially on the poor in his time. From the Biblical data discussed it became clear that Paul's motives for this focus could in some instances even qualify as abject altruism. It must be reiterated, however, that this approach by Paul is frequently connected to Jesus Christ as the suffering servant.

In the last instance, the financial make-up of Paul and the churches where he ministered were viewed from an economic angle. Despite the highly speculative nature of all research and findings in this regard, I reckon that the pendulum is slowly but surely swinging back to the appreciation of the dire circumstances under which believers as well as citizens of Corinth lived during the famines in the time of Paul, and that Paul's living standards would be very much dependent upon the society in which he functioned.

\section{Remembering the poor - back to the future?}

In 1998 Simon Pettit delivered a sermon with the title 'Remember the poor', which would reshape the way that the church should think about its mission in the $21^{\text {st }}$ century. Pettit argues that the ministry to the poor, 
especially as it presents itself in the life of the Early Church, was one of the essential aspects to all the missionary endeavours in the New Testament.

He argued that Jesus and his followers actively practised almsgiving during his ministry on earth, and that this practise gained momentum with the outpouring of the Holy Spirit on the day of Pentecost. According to Pettit did not only the 'love communalism' of the apostles, but also the subsequent correspondence of James and Paul testify to hereof. He furthermore stated that 'the apostle Paul was completely one with the Jerusalem apostles in having burden and a passion for the poor.'

Pettit's statement concurs with an important publication by Meggitt (1998), Paul, poverty and survival. Although evoking intense criticism for his bold claims, stating that up to 99 percent of the First Century population lived in abject poverty (1998:50), Meggitt set the stage for a new interest in poverty in the First Century. Not only was Meggitt's hypothesis pursued by acclaimed scholars such as Friesen and Scheidel (2009), but it surely contributed to Bruce Longenecker's extensive publication, Remember the poor (2010). In this publication Longenecker makes very strong statements which deserve attention in this paper.

Contra common belief, Longenecker argues that the instruction to Paul was not referring to the collection for Jerusalem only or even per se. He argues that the apostles 'added nothing to Paul's message' (Gal. 2:6), but merely urged him to pursue the same missionary method that he was applying already, by caring for the poor (Longenecker 2010:207-219).

It is noteworthy that Longenecker (2010:287-290) also reiterates that the Pauline approach differed from Communism and the general practice of charity within the church. He states that 'economic differences continued to exist within communities of Jesus-followers that Paul established', and that the poor were not simply 'remembered' by tossing a coin to them on the streets'. The poor were, according to Longenecker, not just to be kept at 'arm's length' through charitable gestures, but 'were to be welcomed into the very heart of those communities of fellowship'.

Amidst strong critique of refounding and replicating the first century church, it must be asked if we are still building on the example of the apostles, as we are instructed to do in Ephesians 2:20. 


\section{The Spirit as initiator of reciprocity}

The difference between Ancient reciprocity and First Century reciprocity is highlighted by Crook (2005:515-520) in an article titled Critical notes: Reflections on culture and socio-scientific models. Whilst ancient reciprocity could be mostly classified as equal or symmetrical reciprocity, the idea of 'asymmetrical', altruistic or general reciprocity developed in the Roman patron-client system (Malina 2001:96). Reciprocity is mostly focused on kinship and 'social distance in a family' (Crook 2005:515-516). The 'reciprocity' model explores the bi-lateral exchanging of gifts 'in kind', where 'particular kinds of relationships and obligation' are established between people (Davies 1996:721).

In assessing the extent of reciprocity, it is also important to take into account the means by which reciprocal actions are performed. Despite being used initially to categorise reciprocity from a political angle, the contribution of Parsons (1963) is also worthwhile to assess biblical reciprocity (Neyrey 2005:470). One can achieve a reciprocal relationship via 1) power, 2) commitment, 3) material goods, and 4) influence (Wessels 2011).

Even though the care for the poor was a very visible component in the Old Testament, there are several indications that the advent of Pentecost brought about a quite radical departure from practices of almsgiving by the Jews. In the Jewish background the four groups of disadvantaged peoples, being the widow, the orphan, the poor and the foreigner, were often looked after as a recompense for previous injustices, rather than being an act of abject altruism (Wolterstorff 2008:79). Eventually the admonitions in the prophets, the Maccabean Era, and the time of Jesus prove that this requirement of Old Testament law has seriously been neglected before the outpouring of the Holy Spirit at Pentecost. As pointed out earlier, the care for the poor was probably only exercised by Jesus and his circle of disciples.

The practice of handing out gifts was not at all unfamiliar in the Greek and Roman societies, but it was often limited to people within their own cultural group. Gifts amongst the Greeks and the Romans had a very strong reciprocal character within the framework of benefaction and patronage, where honour and respect was expected in return. This practise was also very seldom directed at the lowest classes of society, being the slaves and the destitute (Longenecker 2010:106-107). Longenecker (2010:287-289) 
goes further and distinguishes Paul's practice of caring for the poor clearly from communism.

It was against this background that Jesus was sent to 'overturn the tables'. Instead of giving with the intent to receive, the Holy Spirit filled the apostles to 'pay it forward'. ${ }^{30}$ The Spirit filled the members of the Early Church in such a way with material goods, inner security, communalism and dignity ${ }^{31}$ in order that they were able to let their blessings flow to the poor around them, in order for everybody to have enough. Eventually these good works would result in the glory of the Triune God, in order for the reciprocal circle to be completed.

The four categories of 'goods' involved in reciprocity is strikingly part and parcel of the gifts of the Holy Spirit. The Holy Spirit fills us with power, commitment, and influence, to make a difference in people's lives (Neyrey 2005:470).

How would one therefore define the Spirit of generosity? The Spirit of generosity would refer to a visible character of giving despite difficult circumstances or grief. It would not only show compassion, but make a difference in situations where it was really needed. It would exceed the boundaries of selfishness to a new level of communal care. It would provide the perseverance and commitment to welfare programs and actions which are so often lacking in our current society. The Spirit of generosity will provide the boldness to seek strategic influence and advocacy, in order to transform oppressing and discriminatory structures.

Generosity as an attribute of the Holy Spirit, and of spirit-filled believers is not to be separated from the other, generally appreciated trademarks of the Holy Spirit. Only when viewed and experienced in co-operation with the power, vision, wisdom and guidance as commonly acknowledged attributes, can the concept of the Spirit of generosity make a real impact in our society.

30 The term 'pay it forward' originates from a striking film with the same name.

31 The well-known Maslow triangle lists these aspects as a human's basic needs. 


\section{The Holy Spirit and poverty - a missing link?}

Current research on the Holy Spirit is still lacking in the area of the Holy Spirit and its function to inspire believers to relieve material poverty. ${ }^{32}$ In discussing the work of the Holy Spirit, Lund (2011:1) lists 70 different functions of the Holy Spirit, without referring once to generosity or poverty, or the poor. There is also an increasing need to develop an African Christology to address poverty (Banda 2012:5).

To my view this has been developed extensively, but needs to be revisited. I do sense, that the real gap in theological research lies in the lack of proper research on the function and understanding of the Holy Spirit regarding the poor. I believe that it is this lack of knowledge that misleads people into keeping their possessions totally to themselves, or establishing an individual financial powerhouse through 'pebbling' with the gospel.

The concept of the Spirit of generosity has definite potential to enrich and contribute to our understanding and experience of the Spirit in the life of the believer. It is the Spirit of generosity that frees believers up to move beyond the borders of their own comfort zone. The Spirit of generosity is moving the church beyond the focus on the gathering and preservation of assets, onto sowing and sending out. Rather than shying away from giving in contexts of poverty, which seems totally overwhelming and impenetrable, the believer is guided towards powerful and focused giving which makes a difference where it counts the most.

The view of the Holy Spirit as the Spirit of generosity will also serve as a catalyst in the growing tendency of prosperity theology. In churches where the spectacular gifts of the Spirit are used towards enriching the coffers of an elite clergy, the focus on and understanding of the Spirit as an initiator of social awareness and action towards making an impact amidst the huge challenges that poverty in Africa poses.

This article does not allow room for extensive discussion and exegesis, but it would be incomplete without an indication of how the role of the Spirit in generosity would change our reading of the several well-known scriptures

32 By this I do not refer to the breaking of the 'spirit of poverty', a coined phrase in many prosperity churches. This theme is often mentioned in connection with separate referrals to the gifts of the Spirit, etc., but neglected as a theme in general. 
in this regard. Jesus starts out his ministry in Luke 4:18 with the wellknown words: 'The Spirit of the Lord is on me, because he has anointed me to preach Good News to the poor.' In this verse the Holy Spirit is clearly linked to the plight of the poor.

In his commentary on this verse Matthey (2000:8) argues that there is always 'a risk to spiritualize the Spirit and to bypass his (or her) interventions in the concrete manifestations of human injustice and suffering.' He proceeds to emphasize the fact that the 'outpouring of the Spirit provokes joy, including ecstatic and charismatic joy (Rom 14:17), which enables intercultural communication, and empowers people for sharing.' He continues to link this passage in Luke to the 'jubilee or remission principle embodied in the first church community as described in Acts 2 and 4.'

A second worthwhile reference is found in Acts 6:2-3, which narrates how seven men, 'full of the Holy Spirit and wisdom' was set apart to focus specifically on the 'daily distribution of food' amongst the widows. Even though the connection is seldom made between the equipment of the deacons by the Holy Spirit for their task of distributing alms to the widows, ${ }^{33}$ it is very relevant to our theme. In this regard Sawyer (2015:15) confirms that the wisdom of the Spirit is essential in serving the poor as community.

Generosity is not only listed in Romans $12: 8$ as a gift of the Spirit, but also in Galatians $6: 7-10^{34}$. The reason why generosity is often overlooked as a gift of the Spirit is because the Holy Spirit is not explicitly mentioned in the immediate context of Romans 12 . Recently texts such as these even prompted a move towards a 'Pentecostal theology of compassion' (Van der Laan 2015).

The passage in Galatians 6:7-10 is clearly directed towards alleviating poverty as 'sowing in the Spirit'. It is noteworthy that the Assemblies of God recently (2009) included the statement that 'the full working of the Holy

33 It is notable that Pieterse (2002:560) describes the role of the church in poverty using Acts 6:1-6 as an example without referring to the role of the Holy Spirit here.

34 Galatians 6:7-10. 'God cannot be mocked. A man reaps what he sows. The one who sows to please his sinful nature, from that nature will reap destruction; the one who sows to please the Spirit, from the Spirit will reap eternal life. Let us not become weary in doing good, for at the proper time we will reap a harvest if we do not give up. Therefore, as we have the opportunity, let us do good to all people, especially to those who belong to the family of the believers.' 
Spirit in expression of fruit and gifts and ministries as in New Testament times' results in 'the edifying of the body of Christ and care for the poor and needy of the world (Sutton \& Mittelstadt 2012:1). This passage is also prominently cited in the scriptural motivation for this declaration.

\section{Conclusion}

From the above it is clear that the Holy Spirit is undoubtedly linked towards the care of the poor and the suffering. In this article it was shown clearly that this connection is multi-dimensional. The work of the Spirit and the care for the poor has a historical connection which dates back to the first century. It has been pointed out how the care for the poor was an integral and prominent part of the ministry of the first Christians. In this ministry the Holy Spirit played a strong role as the initiator of the care of the poor.

Secondly the appreciation of the Spirit as the motivating force behind reaching out to the poor was also approached from an exegetical (and dogmatic) angle. It was shown how several important links in the texts of Acts and other New Testament books was often just overlooked, or downplayed in the past. I am of the opinion that this opens up a new field of exploration, having the potential of reframing the traditional mindset regarding the biblical imperatives for the Holy Spirit's force towards helping and uplifting the suffering and the underprivileged.

Last but not least, it is possible that a focus on the Holy Spirit and generosity may contribute towards closer cooperation between Reformed churches and Pentecostals, especially when it concerns alimentation and almsgiving towards those who live below acceptable subsistence levels. The stigma towards compassion as something that is merely philanthropic and humanistic of nature can be radically changed if the full implications of Spirit-filled generosity can be grasped by congregations and communities.

The following statement of Pettit (1998) provides a befitting end to this article: 'The Gospel is good news for the poor - ... for the have-not's, for the are-not's. Not just the ones from Toronto... For the world.' 


\section{Bibliography}

Banda, DT 2012. Poverty and life with dignity. Unpublished paper delivered at the Joint Conference in Religion and Theology in Pietermaritzburg.

Batten, A 2007. Ideological strategies in the Letter of James, In Webb, RL \& JS Kloppenborg (eds). Reading James with new eyes. London: T\&T Clark. p. 6-26.)

Bible. 1983. The Holy Bible. New International Version. Grand Rapids: Zondervan.

Birch, BC 1975. Hunger, poverty and Biblical religion. The Christian Century 11-18 June:593-599.

Bird, FB 1982. The poor in Israel and the New Testament. Journal of Religious Ethics 10(1):144-169.

Blomberg, CL 1999. Neither poverty nor riches: A biblical theology of possessions. Downers Grove: InterVarsity Press.

Crook, ZA. 2005. Critical notes: Reflections on culture and social scientific models. Journal of Biblical Literature 124(3):515-520.

Culbertson, PL. 1982. Changing images of the Pharisees. Anglican Theological Review 64(4):539-561.

Davids, PH 2005. The test of wealth. In Chilton, B \& P Evans (eds). The missions of James, Peter and Paul: Tensions in early Christianity. Leiden: Brill. p. 355-384.)

Davies, DJ 1996. Reciprocity. In Clarke, PA (ed). Dictionary of ethics, theology and society. New York: Routledge. p. 721-722.)

Fosu, AK. 2015. Growth, inequality and poverty in Sub-Saharan Africa:

Recent progress in a global context. Accessed online: https://doi.org/10.10 80/13600818.2014.964195 Date: 20 August 2016.

Friesen, S \& Scheidel, W. 2009. The Size of the Economy and the Distribution of Income in the Roman Empire. [Online]. Available: https://www.researchgate.net/publication/228273426 [Accessed 7 September 2016]. 
Gapp, KS 1935. The universal famine under Claudius. Harvard Theological Review 28(4):258-265.

Haenchen, E 1971. The Acts of the Apostles. Oxford: Blackwell.

Harrison, EF 1986. Interpreting Acts: the expanding church. Grand Rapids. Zondervan.

Kim, K 1998. Stewardship and almsgiving in Luke's theology. Sheffield: Sheffield Academic Press.

Ling, TJM 2006. The Judaean poor and the Fourth Gospel. Cambridge: Cambridge University Press.

Longenecker, BW 2010. Remember the poor: Paul, poverty and the GraecoRoman World. Grand Rapids, Michigan: Eerdmans.

Malina, BJ 2001. The New Testament world. Insights from cultural anthropology. Louisville: Westminster John Knox Press.

Nissen, J 1984. Poverty and mission. Leiden: Interuniversity Institute for missiological and ecumenical research.

Kim, K 1998. Stewardship and almsgiving in Luke's theology. Sheffield: Sheffield Academic Press.

Lund, T 2011. 70 Functions of the Holy Spirit. [Online].Available: http:// revtrev.com/you-need-to-know/70-functions-of-the-holy-spirit. [Accessed 7 September 2016].

Nolland, J 1989. Luke 1-9:20. Word Biblical Commentary. Nashville: Thomas Nelson.

Matthey, J 2000. Luke 4:16-30. The Spirit's Mission Manifesto. Jesus' hermeneutics and Luke's editorial. International Review of Mission 89:3-11.

Neyrey, JH 2002. Who is poor? [Online] Available: http://americancatholic.org/ sfs/an1002.asp [Accessed 9 November 2002].

Neyrey, JH 2005. God, benefactor and patron: The major cultural model for interpreting the deity in Greco-Roman antiquity. Journal for the Study of the New Testament 27(4):465-492.Parsons 1963 
Pieterse, HJC. 2002. Communicative rationality and hermeneutical insights for preaching in a context of poverty. NGTT 43:555-562.

Pettit, S. 1998. Remember the poor. Sermon delivered at the Newfrontiers Leaders Conference in Brighton. [Online] Available: https:// s3.amazonaws.com/Toam/Remember_the_Poor.mp3 [Accessed 7 September 2016.

Sanders, EP 1992. Judaism: practice and belief, 63 BCE - 66 CE. London: SCM.

Sawyer, W 2015. Christian spirituality and small group effectiveness: A Socio-Rhetorical analysis of Acts 6:1-7. Emerging Leadership Journeys 8:1-21.

Scottroff, L \& Stegemann W 1986. Jesus and the hope for the poor. Maryknoll: Orbis Books.

Sutton, GW \& Mittelstadt, MW 2012. Loving God and loving others: Learning about love from Psychological Science and Pentecostal Perspectives. Journal of Psychology and Christianity 32:157-166.

Van der Laan, PN 2015. 'Towards a Pentecostal Theology of Compassion.' Journal of the European Pentecostal Theological Association 31:36-52.

Volschenk, GJ 2003. Ekonomie in die tyd van die Bybel as 'n huishouding gebaseerde ekonomie. Hervormde Teologiese Studies 59(2):403-431.

Wessels, JM 2011. Triangular Reciprocity: A new perspective on 1 Corinthians 9. Unpublished paper delivered at the SBL in London.

Wessels, JM 2015. Offering the Gospel adapanon: An interpretation and application of 1 Corinthians 9:18. Bamberg: Bamberg University Press.

Wolterstorff, N 2008. Justice: Rights and wrongs. Princeton: Princeton University Press. 